\title{
How to Prevent the Development of Purulent Complications of Acute Pneumonia
}

\author{
Igor Klepikov* \\ Pediatric surgeon, USA
}

Submission: August 28, 2017; Published: September 07, 2017

*Corresponding author: Igor Klepikov, Pediatric surgeon, WA, USA, Email: igor.klepikov@yahoo.com

\section{Introduction}

Treatment of acute pneumonia (AP) in recent decades focused solely on antibiotic therapy, does not include pathogenetic, specific methods of assistance and repeats the principles of treatment of other inflammatory diseases. Moreover, according to existing therapeutic and preventive recommendations, it is possible to assume that the AP is a specific form of inflammation. Existing approaches to the treatment of AP are in stark contrast with the following well known facts.

a) AP is not contagious specific disease.

b) Approval, the priority role of specific pathogens in the etiology of AP have no absolute evidence, for the vast majority of these patients were cured and cure without clarifying the etiology of the disease. Cause a significant increase in septic complications AP, contrary to expectations, on the background of total pneumococcal vaccination remains without a reasoned explanation.

c) The etiology of AP is represented by many non-specific bacteria. These microorganisms are found as a rule among the symbionts of healthy people.

Reducing the effectiveness of antimicrobial drugs,the emergence and the increasing number of antibiotic-resistant pathogens and a gradual increase in the frequency of purulent complications attach importance and urgency to the solution of this problem. The first step in this decision is a revision of ideas about the nature and mechanisms of AP. This work has been done and tested in a clinical setting in the years 1976-1984 in Novokuznetsk State Institute for postgraduate doctors(USSR,Russia). The basis of the new doctrine AP was based on the following scientific medical axioms, already having previous scientific justification.

a) The body's response to any stimulus, including the initiation of inflammation, is highly individual and unique.

b) The basis for the inflammatory transformation of the body tissue is a vascular reaction with a specific stage sequence.

c) Small and big circles of blood circulation not only have a direct relationship,but an inverse relationship.

d) Among the nonspecific forms of inflammation, AP is the only process occurring in the system of lesser circulation.

e) The same medical procedure can have different effects on inflammation in the small or big circles of blood circulation.

Following private studies were additionally performed:

a) Experimental model of AP (4 series of experiments, 44 animals) obtaining a model of pleural complications (certificate for invention No 1631574, A1, 1 November 1990, USSR).

b) X-ray examination 56 lung anatomical preparations with different forms of the AP, taken from the dead patients.

c) Record comparative rheopulmonography before and after performing medical procedures (36 patients).

d) Analysis of the observation and treatment of 994 children with AP and its various destructive and pleural complications.

The revised treatment guidelines were applied in 101 patients in the initial period of aggressive forms of AP. The received results allow to speak about possibility of the guaranteed prevention of suppurative and destructive complications of the disease.

A more detailed presentation and justification of the new doctrine AP, the results of these studies and clinical trials can be found in the published book: Igor Klepikov-"Acute pneumonia: a new look at the old problem", Lambert Academic Publishing, 2017, ISBN (978-3-330-35250-6).

This book gives a detailed understanding of the unique mechanisms of the development of OP and the existing ways of 
influencing them in the direction of stimulation and inhibition. Materials give a real idea about the possibility of guaranteed

This work is licensed under Creative Commons Attribution 4.0 Licens DOI: 10.19080/JHNSS.2017.01.555561 prevention of suppurative and destructive complications of the disease.

\section{Your next submission with Juniper Publishers will reach you the below assets}

- Quality Editorial service

- Swift Peer Review

- Reprints availability

- E-prints Service

- Manuscript Podcast for convenient understanding

- Global attainment for your research

- Manuscript accessibility in different formats

( Pdf, E-pub, Full Text, Audio)

- Unceasing customer service

Track the below URL for one-step submission https://juniperpublishers.com/online-submission.php 